\title{
ANTHROPOMETRY SURVEY OF NIGERIA PARAPLEGICS
}

\author{
S. P. Ayodeji, S.B. Adejuyigbe and A.K. Abiola-Ogedengbe \\ Department of Mechanical Engineering, \\ Federal University of Technology, \\ P. M. B. 704, \\ Akure, Nigeria
}

\begin{abstract}
Measurements of body features and other physical parameters of the human body were taken by the authors of Nigeria paraplegics. Several anthropometric measurements, both static and dynamic categories were taken ranging from height, forward reach to Mid Upper Arm Circumference $(M U A C)$. Data collected were analyzed using percentile basis for the $5^{\text {th }}, 50^{\text {th }}$ and $95^{\text {th }}$ percentile. The result of this survey as presented will serve as a guide and provide anthropometric databank for designers of utilities, workspace and equipments for Nigeria paraplegics.
\end{abstract}

Keywords: Anthropometry, Paraplegics, Survey, Nigeria

\section{INTRODUCTION}

People with lower limb deformities, hitherto called paraplegics depend on mobility aids and other essential utilities to carry out certain important human activities. Such mobility aids includes wheel chair, callipers, crutches, to mention a few. However, for any of such utilities to effectively serve them, proper anthropometry of target users must be taken.

The importance of anthropometry to designs of facilities, workspace and equipments for human use can not be overemphasized. This has necessitated a lot of researchers to carry out activities in this field. To mention a few, Haslegrave (1979) compared British and American drivers' anthropometrics and observed that British driv- ers (male and female) were taller. Omotade (1989) constructed anthropometrics for measuring facial dimensions of new babies. He compared 252 body dimensions of whites in Cardiff with 256 similar dimensions of black babies in Ibadan, Nigeria. He noticed that the phalpebral fissure lengths were significantly different between white and black population. Goswami et al (1987) examined six international studies of people with lower limb disorders and discovered that, for a combined total of 58 body size descriptors measured in the studies, not a single dimension was found in common. Other anthropometry survey works include those undertaken by Oxford (1969), Joan and Kirk (1970), Langdons (1965), Lippert (1962) and Ighoanugo et al (2002).

70 Journal of Science and Technology, Vol. 28, No. 3, Dec., 2008 
Just as human anthropometry follows some anthropographic distribution, ditto those of human paraplegic populations ipso facto. Thus, anthropometry distribution of Nigeria paraplegics would differ from those of other nationals. However, utilities and equipments used by Nigeria paraplegics are usually imported from other countries whose anthropometry distribution differs from ours. Efforts to source anthropometry data of Nigeria paraplegics were unsuccessful. The principal way to achieve good design is through the application of anthropometric data. In order to be effective, however, the data must not only be appropriate to the design at hand but must also be descriptive of the target user population (Bradtmiller and Annis, 1997).

Anthropometry data of Nigeria population was thus taken for various age distributions ranging from 0 to 60 years. A sample size of 100 was taken and 40 different body dimensions were measured using anthropometers, some of which we designed and constructed, while some were bought out. Reliability of the constructed anthropometers was ensured by proper calibration.

\section{METHODOLOGY}

Questionnaires were used to obtain anthropometric data from respondents in Benin, Edo State and Warri, Delta State. These cities are the nucleus of the old Mid-West (later Bendel) state. They are home to varieties of ethnic groups in Nigeria (both minority and majority) partly due to their strategic location and being main source of crude oil; Nigeria's chief export commodity and largest income earner. These cities demography are thus seen as reflective and representative of the Nigerian population.

A sample population of 100 was taken of both male and female respondents. For each respondent, anthropometers designed and constructed for this purpose was used to obtain their data. The calibration of the designed anthropometers in centimetres was carefully done. The weighing scale used is calibrated in Kilogramme $(\mathrm{kg})$. Age measurements were taken verbally or from re- spondents record with organisations they belonged to.

Forty anthropometric parameters were measured. These parameters and their possible areas of application for designs of both equipments and workspaces are shown in Table 1.

\section{ANTHROPOMETERS USED}

Anthropometers used for this survey includes the following:

1. wooden venier calliper

2. standiometer

3. tape rule

4. weighing scale

\section{Description of Anthropometers}

The anthropometers used during the survey are: Wooden Venier Calliper: This is T-shaped wooden equipment. It has a wooden slider running along the longer arm of the Tee. Calibrations in $\mathrm{cm}$ were provided along the longer arm of the Tee where the readings shall be read from the calliper.

Standiometer: This is made of wood with $\mathrm{cm}$ caliberations provided at one end. It is a long standing rod where respondents are made to stand to the maximum height they can reach, while the measurement is read.

Tape Rule: The tape rule is a purchased item. It is made of latex material and has calibrations in centimeter and inches on opposite sides. Its flexibility allows it to be used for different measurements like waist circumference, head circumference, hip circumference (Standing), Middle Upper Arm Circumference (MUAC), etc. The tape rule has a range of $150 \mathrm{~cm}$. See figure 1c.

The weighing scale: The weighing scale was purchased as manufactured from the store. It has a flat surface on which subject can stand while the scale calibrated in Kilogram can be read to ascertain the weight of subject. The capacity of the scale is $120 \mathrm{Kg}$

\section{Reliability of Anthropometers}

The anthropometers used were carefully calibrated and readings during the survey were re- 
peatedly taken to ensure correctness. Most readings taken remained unchanged during the repeat measurement to confirm the reliability of the antropometers.

Table 1: Anthropometry parameters and possible area of applications

\begin{tabular}{|c|c|}
\hline Category & $\begin{array}{c}\text { Possible Area of Application } \\
\text { (Industrial and domestic equipment \& workspace designs) }\end{array}$ \\
\hline \multicolumn{2}{|l|}{ Age } \\
\hline Height & Vertical standing clearance \\
\hline Weight & Seat design \\
\hline Sitting height & Vertical sitting clearance \\
\hline Forward reach & Horizontal grasping reach \\
\hline Maximum body width & Lateral Clearance \\
\hline Eye height sitting & Placement of visual display \\
\hline Mid shoulder height & Garments design \\
\hline Buttock to popliteal & Establishment of seat length \\
\hline Buttock to knee length & Horizontal leg room \\
\hline Popliteal height (sitting) & Seat height \\
\hline Knee height (sitting) & Vertical leg room \\
\hline Thigh clearance (sitting) & Seat and lower clearance \\
\hline Elbow to fingertip & Operator control clearance \\
\hline Chest circumference & Garments design \\
\hline Shoulder circumference & Garments design \\
\hline Hip (buttock) circumference & Garments design \\
\hline Head breadth & Head gear design \\
\hline Head circumference & Head gear design \\
\hline Inter pupilliary breadth & Eye goggle design \\
\hline Waist circumference & Garments design \\
\hline Waist depth & Waist strap, Garments design \\
\hline Buttocks to heel length & Leg clearance \\
\hline Shoulder breadth & Width for central working area, wheel chair, garments design, etc \\
\hline Hip breadth & Seat breadth \\
\hline Forearm to forearm breadth & Back rest with lateral clearance \\
\hline Head height & Head gears \\
\hline Head length & Head gears \\
\hline Eye to top of head length & Head gears, protective helmet design \\
\hline Chin to eye height & Protective helmet strap design \\
\hline Neck circumference & Garments design \\
\hline $\begin{array}{l}\text { Hand length } \\
\text { Hand breadth at metacarpal }\end{array}$ & $\begin{array}{l}\text { Hand protectors and grip } \\
\text { Hand protective gears }\end{array}$ \\
\hline Hand breadth at thumb & Hand protective gears and lateral hand clearance \\
\hline Hand thickness at metacarpal & Hand protective gears \\
\hline Foot length & Foot wears \\
\hline Ball of foot width & Foot wears \\
\hline $\begin{array}{l}\text { Mid Upper Arm Circumference } \\
\text { Abdominal girth }\end{array}$ & $\begin{array}{l}\text { Arm strap, Garments design } \\
\text { Garments design }\end{array}$ \\
\hline Mid-thigh circumference & Callipers design, Trousers design \\
\hline
\end{tabular}

72 Journal of Science and Technology, Vol. 28, No. 3, Dec., 2008 
ANTHROPOMETRY PARAMETERS

Forty anthropometry parameters were measured and they are hereby illustrated graphically in Figures 1a-ap

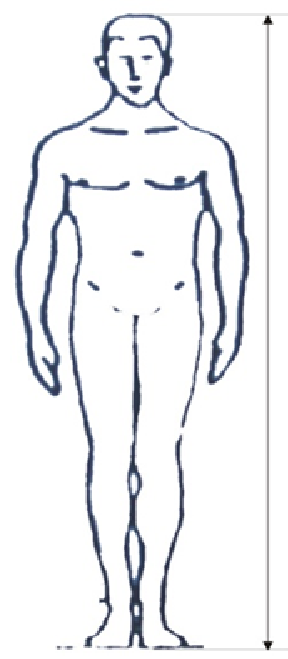

Fig. 1a: Height

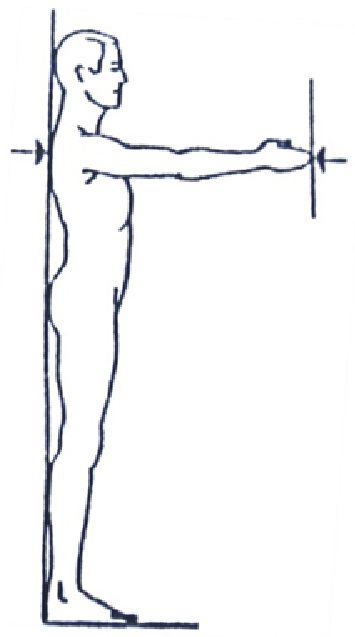

Fig. 1c: Forward Reach

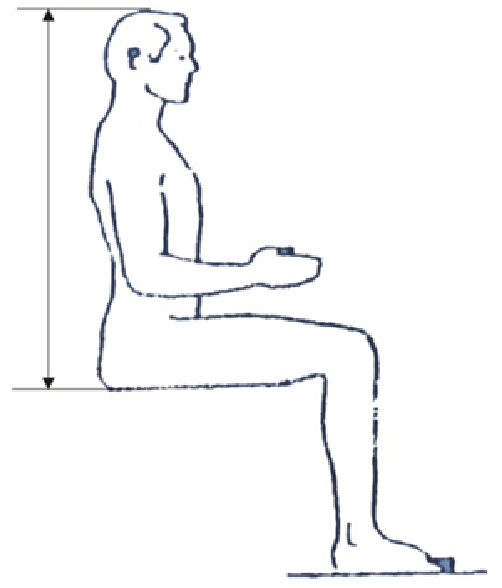

Fig. 1b: Sitting Height

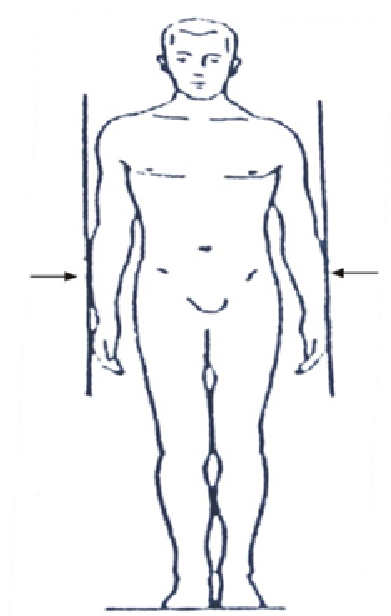

Fig. 1d: Maximum Body Width 


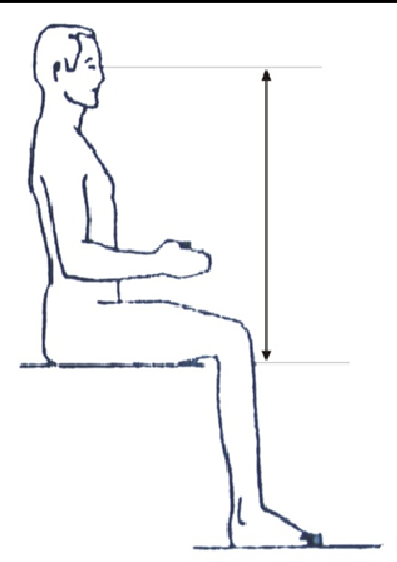

Fig. 1e: Eye Height Sitting

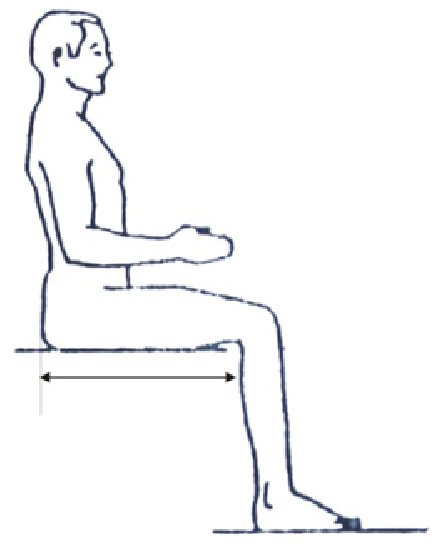

Fig.1g: Buttock To Popliteal

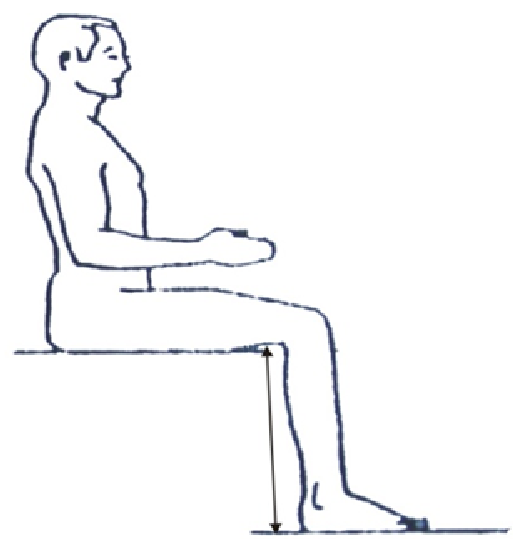

Fig 1i: Popliteal Height

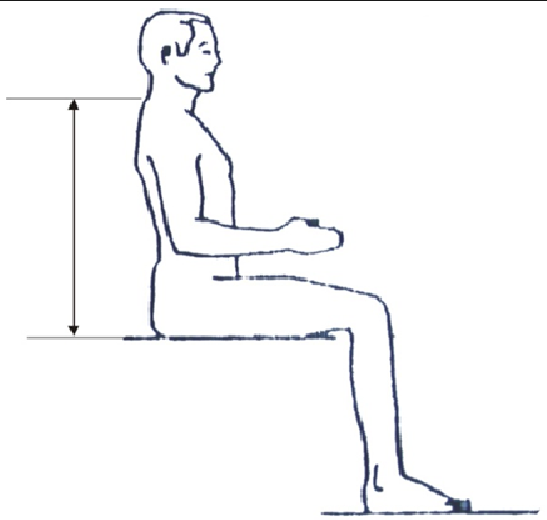

Fig. 1f: Mid Shoulder Height

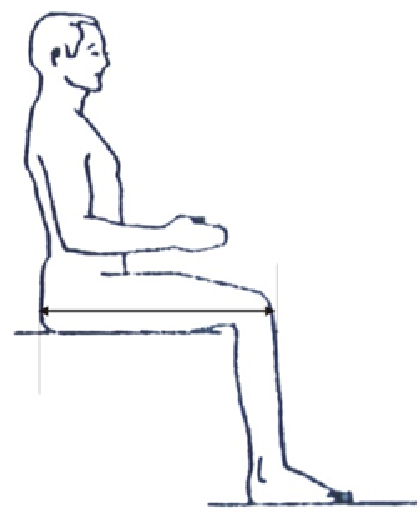

Fig 1h: Buttock To Knee 


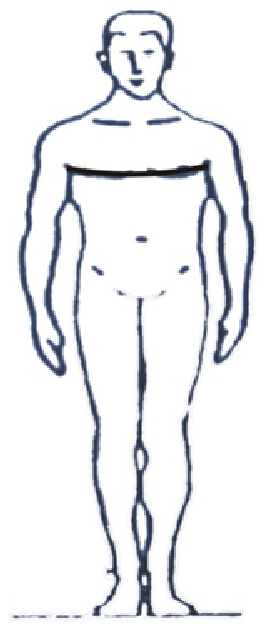

Fig. 1k: Chest Circumference

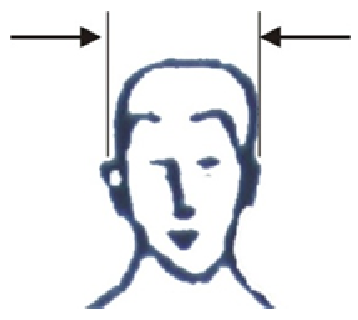

Fig. 1m: Head Breadth

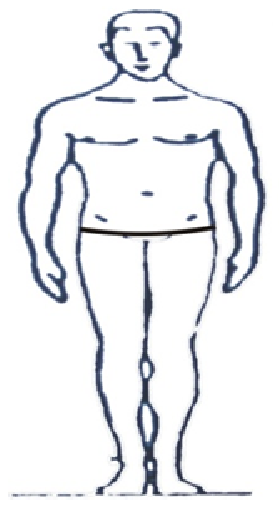

Fig. 1p: Hip Circumference
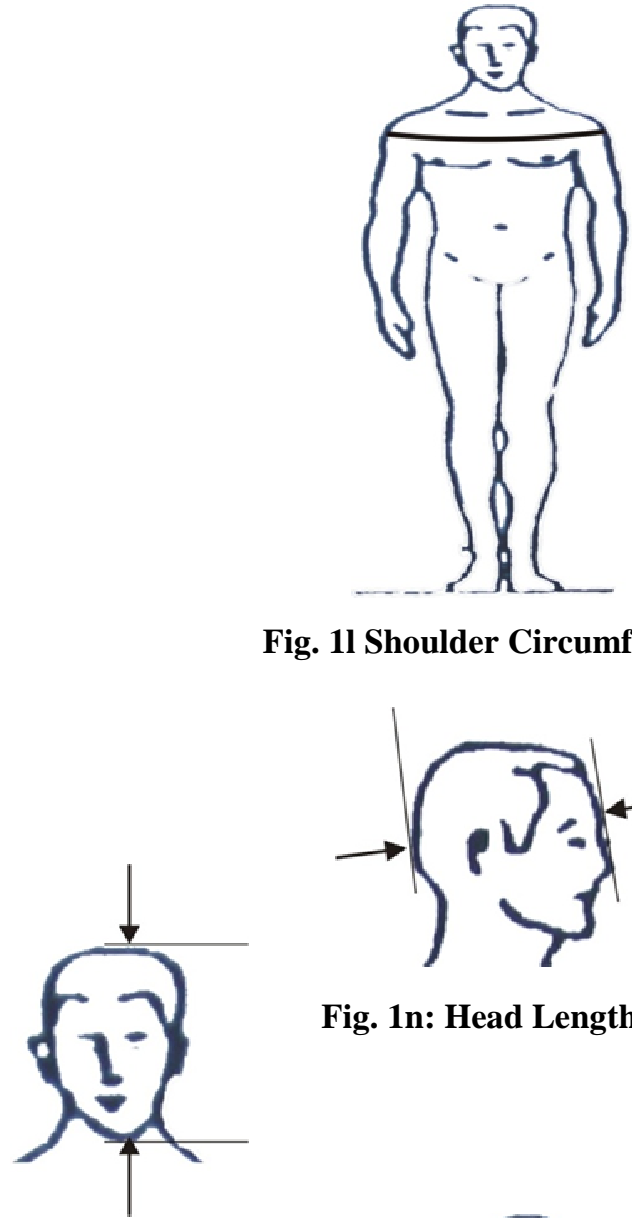

Fig. 1l Shoulder Circumference

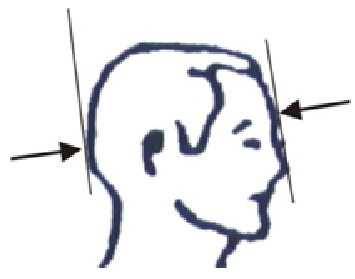

Fig. 1n: Head Length

Figure 10: Head Height

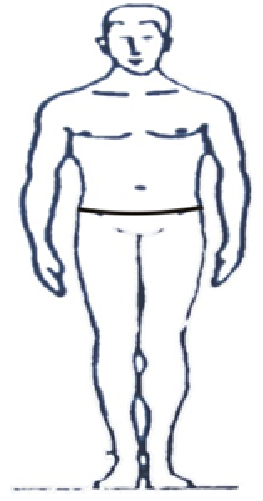

Fig. 1r: Waist Circumference 


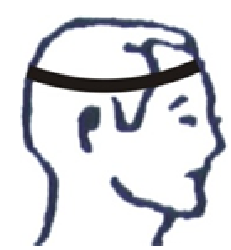

Fig. 1s: Head Circumference

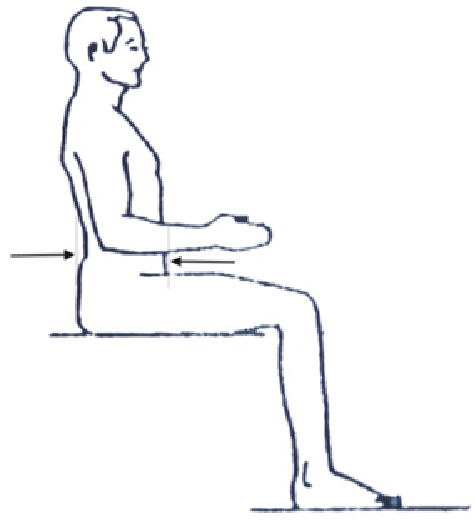

Fig. 1w Waist Depth

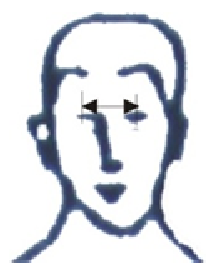

Fig. 1t: Inter-Pupilliary Breadth

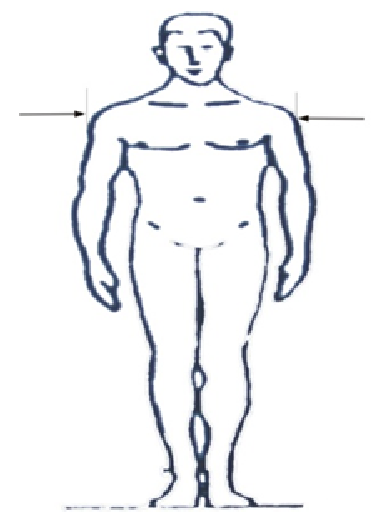

Fig. 1x: Shoulder Breadth

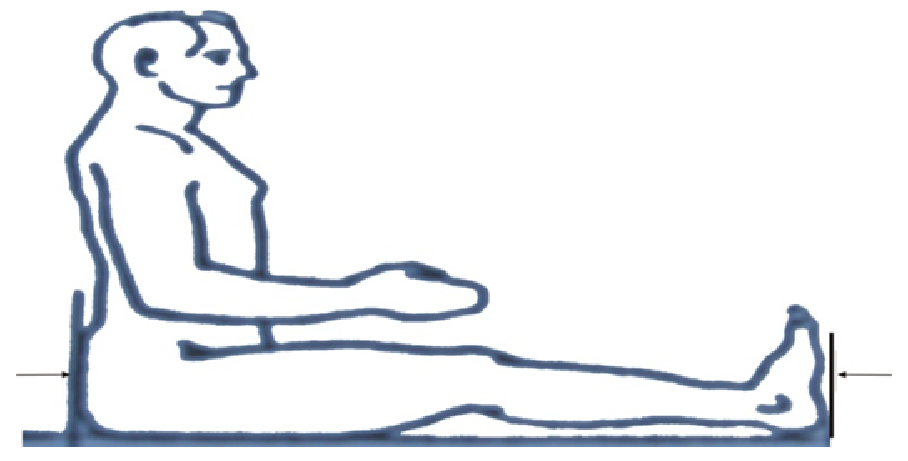

Fig. 1y: Buttock To Heel Length

76 Journal of Science and Technology, Vol. 28, No. 3, Dec., 2008 


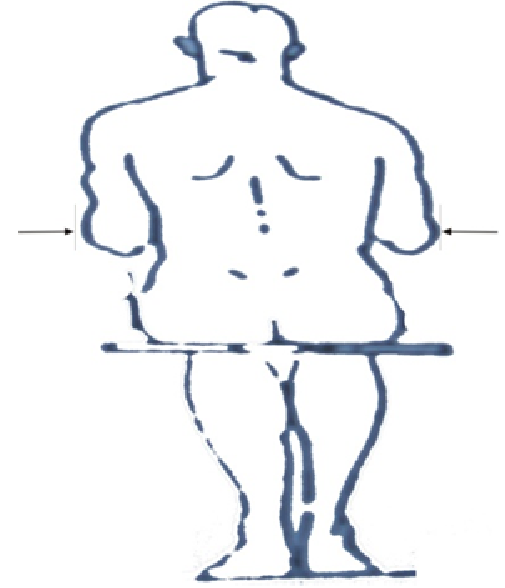

Fig. 1z: Forearm To Forearm Breadth

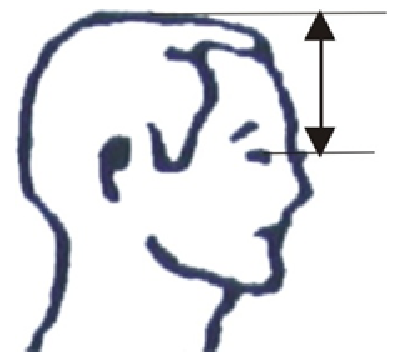

Fig. 1ab: Eye To Top Of Head Length

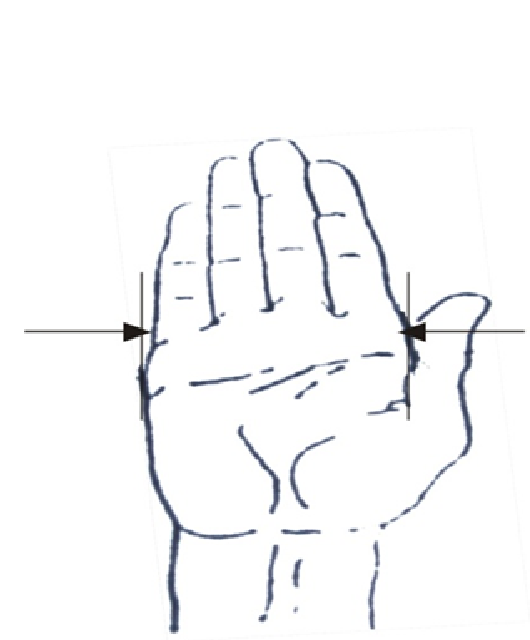

Fig. 1ae: Hand Breadth At Metacarpal

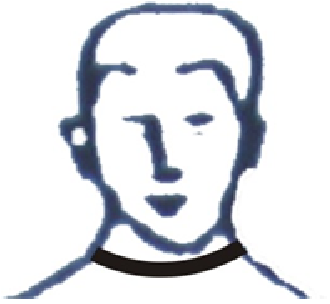

Fig. 1ad: Neck Circumference

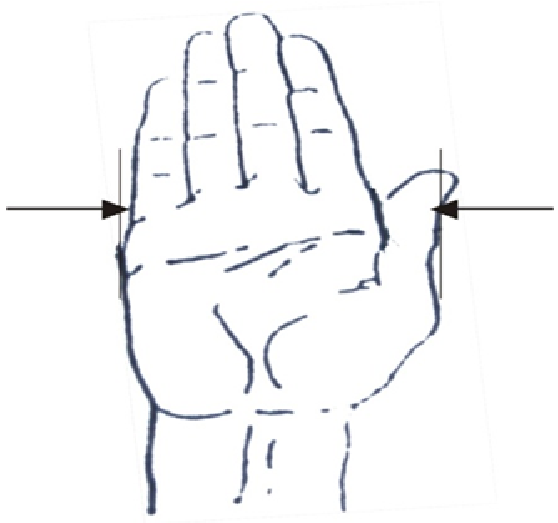

Fig. 1af: Hand Breadth At Thumb

Fig. 1aa: Abdominal Girth

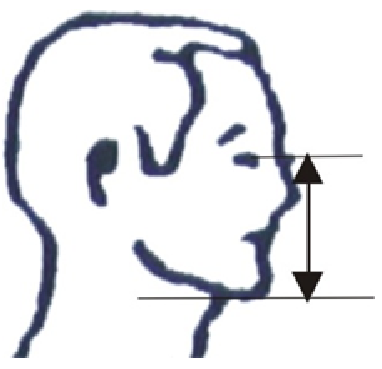

Fig. 1ac: Chin To Eye Height 


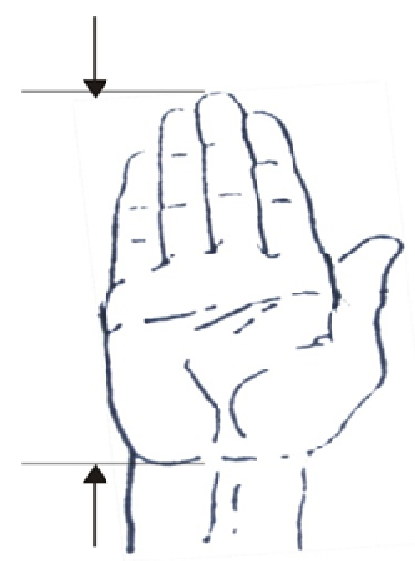

Fig 1ag: Hand Length

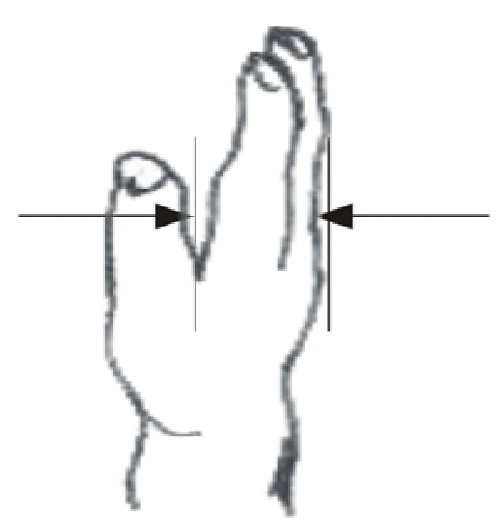

Fig. 1ah: Hand Thickness At Metacarpal

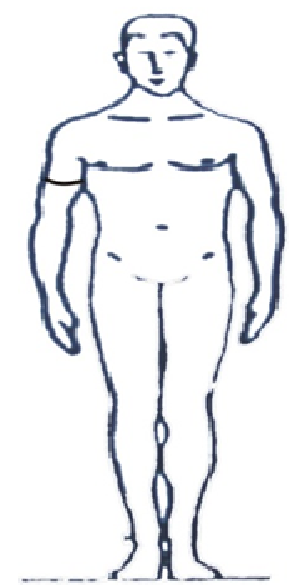

Fig. 1aj: Muac

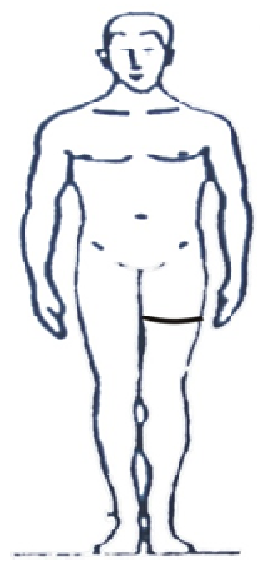

Fig. 1ak: Mid-Thigh Circumference

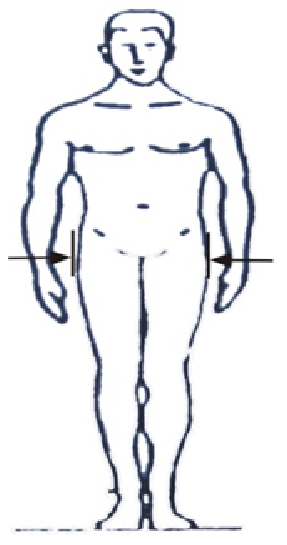

Fig. 1am: Hip Breadth

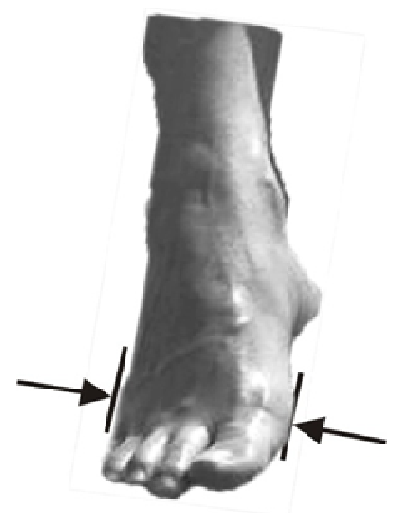

Fig. 1an: Ball Of Foot Width

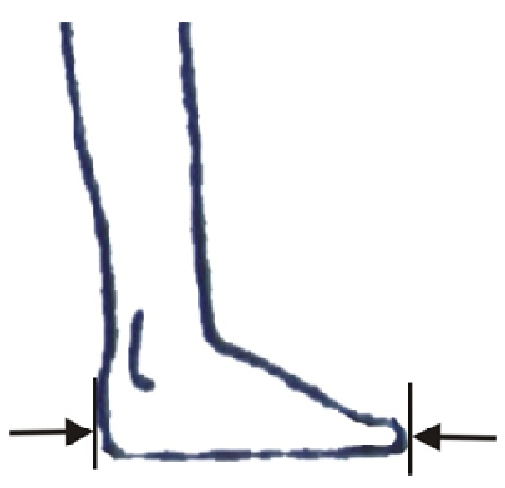

Fig. 1ap: Foot Length

78 Journal of Science and Technology, Vol. 28, No. 3, Dec., 2008 


\section{RESULTS AND DISCUSSION}

The anthropometric parameters measured were all in centimetres and the analysis presented in tables and figures above reveal similarities in the body sizes of paraplegic male and females except that males have generally higher values than females except in certain physical features which are more prominent in females. These ones include chest circumference, hip (buttock) circumference and hip breadth. This survey further reveals that the human anthropometry does not necessarily follow a particular pattern. Someone with long legs may not necessarily have long arms and vice versa. Also, an older

Table 2: Percentile Distributions for Male Paraplegics

\begin{tabular}{|c|c|c|c|}
\hline Category & $5^{\text {th }}$ percentile & $5^{\text {th }}$ percentile & $9^{\text {th }}$ percentile \\
\hline Age & 8 & 24 & 46 \\
\hline Height & 118.21 & 148 & 163.5 \\
\hline Weight & 20 & 45 & 56.2 \\
\hline Sitting height & 57.45 & 69.5 & 78.875 \\
\hline Forward reach & 61.225 & 75 & 90 \\
\hline Maximum body width & 29 & 40 & 55 \\
\hline Eye height sitting & 49.45 & 63 & 70 \\
\hline Mid shoulder height & 41.45 & 52.25 & 60 \\
\hline Buttock to popliteal & 29.725 & 37.5 & 44 \\
\hline Buttock to knee length & 36 & 44.25 & 54 \\
\hline Popliteal height (sitting) & 31 & 41 & 50.11 \\
\hline Knee height (sitting) & 37 & 50.5 & 62.1 \\
\hline Thigh clearance (sitting) & 8 & 9 & 12 \\
\hline Elbow to fingrtip & 36.225 & 44 & 51.775 \\
\hline Chest circumference & 62.225 & 82 & 101.3 \\
\hline Shoulder circumference & 71.45 & 96.5 & 118.375 \\
\hline Hip (buttock) circumference & 56.15 & 75 & 87.7 \\
\hline Head breadth & 15 & 17 & 21 \\
\hline Head circumference & 51 & 55 & 63.695 \\
\hline Inter pupilliary breadth & 7 & 8.75 & 10.775 \\
\hline Waist circumference & 57 & 69.1 & 85.55 \\
\hline Waist depth & 16 & 20 & 24.1 \\
\hline Buttocks to heel length & 67.45 & 94.5 & 106.55 \\
\hline Shoulder breadth & 31 & 36.5 & 45.1 \\
\hline Hip breadth & 20.45 & 27.5 & 32 \\
\hline Forearm to forearm breadth & 32 & 40 & 49 \\
\hline Head height & 19 & 22 & 27 \\
\hline Head length & 20 & 24 & 28 \\
\hline Eye to top of head length & 7 & 10 & 14.055 \\
\hline Chin to eye height & 11 & 13 & 15 \\
\hline Neck circumference & 27 & 34 & 41.55 \\
\hline Hand length & 14 & 18 & 23.55 \\
\hline Hand breadth at metacarpal & 6 & 10 & 11 \\
\hline Hand breadth at thumb & 8 & 12 & 14 \\
\hline Hand thickness at metacarpal & 2 & 3 & 4 \\
\hline Foot length & 16 & 22 & 25.06 \\
\hline Ball of foot width & 6 & 10 & 12.955 \\
\hline MUAC & 17 & 22.8 & 34.275 \\
\hline Abdominal girth & 53 & 65.05 & 85.1 \\
\hline Mid-thigh circumference & 21 & 29 & 40.6 \\
\hline
\end{tabular}


person may also not necessarily have higher anthropometric values than a younger person. There were also subjects which were found to have unusual anthropometry features which could be regarded as cases of abnormality. Table 2 shows the percentile distribution of male paraplegic population while Table 3 presents those of the female population.

Table 3: Percentile Distributions for Female Paraplegics

\begin{tabular}{|c|c|c|c|}
\hline Category & $5^{\text {th }}$ percentile & $50^{\text {th }}$ percentile & $95^{\text {th }}$ percentile \\
\hline Age & 5.45 & 19.5 & 46.55 \\
\hline Height & 116.45 & 137 & 155.55 \\
\hline Weight & 18.45 & 38.5 & 55 \\
\hline Sitting height & 57 & 68 & 74.825 \\
\hline Forward reach & 58 & 69 & 81 \\
\hline Maximum body width & 27.725 & 37.5 & 51.55 \\
\hline Eye height sitting & 50 & 60.25 & 67 \\
\hline Mid shoulder height & 42.45 & 52 & 59 \\
\hline Buttock to popliteal & 29.45 & 35 & 42.275 \\
\hline Buttock to knee length & 35 & 41.5 & 49 \\
\hline Popliteal height (sitting) & 30 & 36.5 & 44.55 \\
\hline Knee height (sitting) & 34.725 & 42.35 & 50.55 \\
\hline Thigh clearance (sitting) & 8 & 9 & 12 \\
\hline Elbow to fingertip & 34 & 39 & 49.55 \\
\hline Chest circumference & 60.45 & 91 & 103.1 \\
\hline Shoulder circumference & 71.45 & 96.5 & 108.65 \\
\hline Hip (buttock) circumference & 56.725 & 86 & 94 \\
\hline Head breadth & 16 & 22 & 27 \\
\hline Head circumference & 51.725 & 55 & 59.55 \\
\hline Inter pupilliary breadth & 7 & 8.8 & 10.275 \\
\hline Waist circumference & 57 & 70 & 82.55 \\
\hline Waist depth & 16 & 18 & 22.55 \\
\hline Buttocks to heel lengt & 61 & 71.5 & 84.605 \\
\hline Shoulder breadth & 31.45 & 40 & 44 \\
\hline Hip breadth & 22 & 29 & 35 \\
\hline Forearm to forearm breadth & 33 & 41.5 & 46 \\
\hline Head height & 18.225 & 22 & 24.55 \\
\hline Head length & 18.45 & 21 & 23.5 \\
\hline Eye to top of head length & 8 & 9.25 & 11 \\
\hline Chin to eye height & 9 & 11 & 12 \\
\hline Neck circumference & 26 & 31 & 41.55 \\
\hline Hand length & 15 & 19 & 23 \\
\hline Hand breadth at metacarpal & 6.225 & 9 & 11 \\
\hline Hand breadth at thumb & 8 & 11 & 13 \\
\hline Hand thickness at metacarpal & 2 & 3 & 3 \\
\hline Foot length & 16 & 20.25 & 23 \\
\hline Ball of foot width & 6 & 9 & 11.275 \\
\hline Muac & 17 & 27.5 & 32.55 \\
\hline Abdominal girth & 55.45 & 76 & 82 \\
\hline Mid-thigh circumference & 21.45 & 29 & 33.55 \\
\hline
\end{tabular}

80 Journal of Science and Technology, Vol. 28, No. 3, Dec., 2008 


\section{CONCLUSION}

Following the collection of anthropometric data of Nigeria paraplegics, efforts have been made to analyse this data

The analysis on percentile basis will be useful to designers for the Nigerian and African market in taking care of the needs of the paraplegics in this region. The $5^{\text {th }}$ and $95^{\text {th }}$ percentile presented will ensure the designs could be made to accommodate large percentage of paraplegic populations in this region.

Local manufacturers in Nigeria are implored to tap into the resource established by this job to design and manufacture for the Nigeria paraplegics. Major tools and utilities used by the paraplegics in Nigeria, currently being imported will be manufactured within.

Aside cost reduction, the local manufacturers stand a competitive advantage by achieving better user friendliness of their products through the use of this resource. Thanks to several nongovernmental organisations, the Nigeria paraplegic populations which are mostly found on the streets un-catered and with no resources of their own are now being housed and catered for. Thus the local manufacturers will definitely have a market for their products.

\section{ACKNOWLEDGEMENT}

The authors wish to appreciate the following people for their contributions in the course of this research especially during the field survey. Mr. Abiola F. Ogedengbe for taking us round the locations. Mr. Ben Onoshemo, Miss Juliet and Hon. Solomon Ighrakpata of the Solomon Ighrakpata Foundation. Major Joy Umoh and Captain John of the Salvation Army Rehabilitation Centre, Benin, Nigeria

\section{REFERENCES}

Bradtmiller Bruce and Annis James (1997). Anthropometry for Persons with Disabilities: Needs for the 21st Century prepared for U.S. Architectural and Transportation Barriers compliance board under contract no. qa96001001 retrieved from http://www. access-board.org/research/anthropometry for persons with disabilities.htm

Goswami, A., Ganguli, S., and Chatterjee, B. B. (1987). Anthropometric Characteristics of Disabled and Normal Indian Men. Journal of Ergonomics. 30(5):817-823.

Haslegrave, C. M. (1979). Anthropometric profile of the British Car Driver. Journal of Ergonomics. 22(2): 145-153

Igboanugo, A. C., Egharevba, F. and Ibhadode, A. O. A. (2002). Anthropometric survey of Nigeria Adult Working Class. Nigerian Journal of Engineering Management. 3(2): 7-20.

Joan, W. and Kirk, N. S. (1970). The Relation between some Anthropometric Dimensions and Preferred working surface height in kitchens. Journal of Ergonomics. 22(2):123139.

Langdons, J. F. (1965). The Design of Card Punches and the Sealing Operator. Journal of Ergonomics 8: 61-68.

Lipperts (1962). Ergonomics Needs in Developing Country. Journal of Ergonomics. 10(5): 617-626.

Omotade, O. V. (1989). Facial Measurements in the New Born (Forward Syndrome). Journal of Medical Genetics. 1:67-80.

Oxford, H. W. (1969). Anthropometric studies in Swedish Industrial works when Standing and Sitting. Journal of Ergonomics. 12(2): 883-902. 